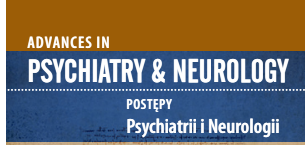

Correspondence to/

Adres do korespondencji:

dr hab. Adam Wichniak

III Klinika Psychiatryczna

Instytut Psychiatrii i Neurologii

ul. Sobieskiego 9

02-957 Warszawa

phone: +48224582556

e-mail:wichniak@ipin.edu.pl

Submitted/Otrzymano: 28.05.2017

Accepted/Przyjęto do druku: 23.08.2017

\section{PATIENT COMPLAINING \\ OF AN IRREGULAR SLEEP RHYTHM - CASE STUDY}

\author{
PACJENT SKARŻĄCY SIĘ NA \\ NIEREGULARNY RYTM SNU - \\ OPIS PRZYPADKU
}

\author{
Adam Wichniak ${ }^{1,2}$, Aleksandra Wierzbicka², \\ Katarzyna Szaulińska', Ewa Poradowska', \\ Wojciech Jernajczyk ${ }^{2}$
}

'Third Department of Psychiatry, Institute of Psychiatry and Neurology, Warsaw, Poland 2Department of Clinical Neurophysiology, Center for Sleep Medicine, Institute of Psychiatry and Neurology, Warsaw, Poland

'III Klinika Psychiatryczna, Instytut Psychiatrii i Neurologii w Warszawie, Polska 2Zakład Neurofizjologii Klinicznej, Ośrodek Medycyny Snu, Instytut Psychiatrii i Neurologii w Warszawie, Polska

\begin{abstract}
Purpose: Delayed sleep-wake phase disorder is the most common circadian rhythm sleep disorder. The aim of this article is to describe the case of a man whose unhealthy lifestyle and improper treatment made delayed sleep-wake phase disorder turn into non-24-hour sleep-wake rhythm disorder.

Case description: A 26-year old patient reported to a sleep disorder outpatient clinic, complaining of an irregular sleep rhythm. He said that from the beginning of the primary school, he had problems with falling asleep and waking up in the morning to go to school. These difficulties got more severe during adolescence and after he started his college studies. The rhythm of sleep became irregular and the need to sleep increased to 13 hours a day. The treatment involved behavioural interventions combined with melatonin $5 \mathrm{mg} /$ day and phototherapy, in line with the procedures of chronobiological treatment of sleep rhythm disorders.

Comment: Chronobiological interventions, such as monitoring of adherence to sleep hygiene rules with an emphasis on fixed, regular times of waking up (and falling asleep) both on weekdays and weekends, while limiting the use of multimedia devices emitting light, at least one hour before going to bed, play an important role in the treatment of delayed sleep-wake phase disorder. Failure to meet these rules makes the symptoms of the disorder more severe and in extreme cases can lead to total loss of synchronisation of the sleep and wake rhythm with the day and night rhythm.
\end{abstract}

Key words: circadian sleep and wake rhythm disorders, delayed sleep phase, diagnosis, treatment.

\title{
Streszczenie
}

Cel: Zaburzenie z opóźnioną fazą snu i czuwania jest najczęstszym zaburzeniem rytmu okołodobowego snu. Celem artykułu jest opisanie przypadku mężczyzny, u którego niehigieniczny tryb życia i niewłaściwe leczenie spowodowały przejście tego typu zaburzenia w zaburzenie z innym niż 24-godzinny rytmem snu i czuwania.

Opis przypadku: Pacjent w wieku 26 lat zgłosił się do poradni leczenia zaburzeń snu ze skargami na nieregularny rytm snu. Opisał, że już od czasu rozpoczęcia szkoły podstawowej miał problemy z zasypianiem i wstawaniem rano do szkoły. Trudności te narosły w okresie adolescencji oraz po rozpoczęciu studiów. Rytm snu stał się nieregularny, a potrzeba snu wzrosła do 13 godzin w ciągu doby. W leczeniu zastosowano interwencje behawioralne w połączeniu z terapią melatoniną $5 \mathrm{mg} /$ dobę i fototerapią, zgodnie z zasadami chronobiologicznego leczenia zaburzeń rytmu snu.

Komentarz: W leczeniu zaburzenia z opóźnioną fazą snu i czuwania ważną rolę odgrywają interwencje chronobiologiczne: przestrzeganie zasad higieny snu, ze szczególnym uwzględnieniem stałych, regularnych pór wstawania (i zasypiania) zarówno w dni robocze, jak i w weekendy, z jednoczesnym ograniczaniem korzystania z wszelkich urządzeń multimedialnych emitujących światło na co najmniej godzinę przed położeniem się do łóżka. Brak przestrzegania tych zasad nasila objawy zaburzenia, w skrajnych przypadkach może też prowadzić do całkowitej utraty synchronizacji rytmu snu i czuwania z rytmem dnia i nocy.

Słowa kluczowe: zaburzenia rytmu okołodobowego snu i czuwania, opóźnienie fazy snu, diagnoza, leczenie. 


\section{PURPOSE}

In 1879 , an event occurred that materially affected the biological and social functioning of people. It was the invention of the light bulb by Thomas Edison. Soon after the electric light has become so accessible and cheap that the current world order, where the day was reserved for being active and the night for resting, ceased to be valid. The use of artificial light in the evening and at night became natural for inhabitants of developed countries. An accurate biological mechanism, called the circadian rhythm, which was developed in the course of evolution to optimise the functioning of the human being during the day and night, was put to the test. The physical factor that synchronises it most strongly, i.e. the light, suddenly began to work against it instead of making it stronger. Currently, nearly 140 years after the invention of the light bulb by Edison, insomnia and circadian rhythm sleep disorders are ones of the most common health problems experienced by the society. The associated social and economic costs far exceed the costs of many other serious brain diseases, such as epilepsy, multiple sclerosis and Parkinson's disease [1].

Dysregulation of biological rhythms, including the strongest one, i.e. the circadian rhythm, has a number of negative consequences for human health. Physiological processes and parameters that exhibit the circadian rhythm in the human body and are subject to changes adverse to human health when this rhythm is disrupted include core body temperature, metabolism and energy homeostasis, the rhythm of the heart, peripheral vascular resistance and blood pressure, blood viscosity and plasma fibrinolytic activity, synthesis and release of proinflammatory cytokines and hormones (such as cortisol, melatonin, prolactin and growth hormone), secretion of gastric juice not related to food, flow and expiratory volume of the lungs [2]. Sleep and wake rhythm disorders are the most noticeable symptom of a disturbed circadian rhythm. Their occurrence not only significantly deteriorates somatic and mental health, but also adversely affects the quality of life.

The aim of the article is to describe the case of a young man who reported to a sleep disorder outpatient clinic, complaining of an irregular sleep rhythm that made it completely impossible for him to function on the day-to-day basis and that adversely affected his mental state.

\section{CASE DESCRIPTION}

A 26-year old patient reported to a sleep disorder outpatient clinic, complaining of an irregular, changeable sleep rhythm. He said that from the beginning of the primary school he had trouble falling asleep and wake up in
CEL

W 1879 r. miało miejsce zdarzenie, które istotnie wpłynęło na funkcjonowanie biologiczne i społeczne człowieka - było nim wynalezienie przez Thomasa Edisona żarówki. Wkrótce potem światło elektryczne stało się tak dostępne i tanie, że dotychczasowy porządek świata, w którym do aktywności służył dzień, a do spoczynku noc, przestał obowiązywać. Korzystanie ze sztucznego światła w godzinach wieczornych i nocnych stało się dla mieszkańców krajów rozwiniętych zachowaniem naturalnym. Precyzyjny mechanizm biologiczny, nazywany rytmem okołodobowym, który wykształcił się w trakcie ewolucji, aby optymalizować funkcjonowanie człowieka w ciągu doby, został poddany niezwykłej próbie. Czynnik fizyczny, który najsilniej go synchronizuje, czyli światło, nagle zamiast go wzmacniać, zaczął pracować przeciwko niemu. Obecnie, blisko 140 lat od wynalazku Edisona, bezsenność oraz zaburzenia rytmu okołodobowego snu i czuwania należą do jednych $\mathrm{z}$ najczęstszych problemów zdrowotnych w społeczeństwie. Koszt społeczny i ekonomiczny z nimi związany znacznie przewyższa koszt wielu innych ciężkich chorób mózgu, np. padaczki, stwardnienia rozsianego, choroby Parkinsona [1].

Rozregulowanie rytmów biologicznych, w tym najsilniejszego z nich - rytmu okołodobowego, ma szereg negatywnych następstw dla zdrowia człowieka. Do procesów i parametrów fizjologicznych, które w organizmie człowieka wykazują rytmikę okołodobową i ulegają niekorzystnym dla stanu zdrowia zmianom $\mathrm{w}$ jej zaburzeniach, należą m.in.: głęboka temperatura ciała, metabolizm i homeostaza energetyczna, rytm czynności serca, opory naczyń obwodowych i ciśnienie tętnicze krwi, lepkość krwi i aktywność fibrynolityczna osocza, synteza i uwalnianie cytokin prozapalnych oraz hormonów (np. kortyzolu, melatoniny, prolaktyny, hormonu wzrostu), niezwiązana $\mathrm{z}$ pokarmem sekrecja soku żołądkowego, przepływ i objętość wydechowa płuc [2]. Najbardziej zauważalnym objawem zaburzonego rytmu okołodobowego są zaburzenia rytmu snu i czuwania. Ich wystąpienie istotnie pogarsza nie tylko stan zdrowia zarówno somatycznego, jak i psychicznego, lecz także negatywnie wpływa na jakość życia.

Celem artykułu jest opisanie przypadku młodego mężczyzny, który zgłosił się do poradni leczenia zaburzeń snu, skarżąc się na nieregularny rytm snu, całkowicie uniemożliwiający mu codzienne funkcjonowanie i negatywnie wpływający na jego samopoczucie psychiczne.

\section{OPIS PRZYPADKU}

Pacjent $\mathrm{w}$ wieku 26 lat zgłosił się do poradni leczenia zaburzeń snu ze skargami na nieregularny, zmienny rytm snu. Opisał, że już od czasu rozpoczęcia szkoły podsta- 
the morning to go to school. These difficulties got more severe during adolescence. At that time, it was possible for him to fall asleep as late as at 3:00 a.m. For this reason, the patient was notoriously sleepy, was falling asleep and was late for school. He was exhausted at school before noon. He felt well only in the evening. Late evening hours and the night were his favourite time of learning and using a computer for pleasure. The problems with falling asleep and lack of sleep on school days were compensated for by the patient by sleeping longer at weekends. The time of getting up in the morning on Saturdays and Sundays was gradually delayed; he even got up as late as early afternoon. The secondary-school graduation year was a very difficult period for the patient as the teachers no longer tolerated his being late for school and being inactive during classes. Then, he began psychiatric treatment. He took standard hypnotics (zolpidem, zopiclone), and then also more potent drugs (nitrazepam, estazolam). They made it easier for him to fall asleep, but did not significantly improve his functioning in the morning. They gradually became ineffective and attempts to increase their doses caused an excessive sedation in the morning. Mood disorders, the feeling of sadness, failure to find enjoyment in activity and constant fatigue also appeared. The patient started to take antidepressant drugs from the group of serotonin reuptake inhibitors (patient reported that attempts were made to use several drugs which were poorly tolerated by him; finally, sertraline $50 \mathrm{mg}$ /day was chosen) with partial improvement of mental health, but not the rhythm of sleep. The patient's health was significantly improved after he started his studies. The improvement due to the fact that it was not necessary for him to get up in the morning lasted several months during which the rhythm of sleep continued to get delayed, and the time of sleep shifted to the period between 4:00 a.m. - 5:00 a.m. and 1:00 p.m. - 2:00 p.m. Soon, the patient was not able to attend the morning classes. He did not receive a credit for his classes and was suspended. Throughout this period the patient intensively used his computer in the evening and at night. His activity in the morning was very low. The rhythm of his meals also shifted to afternoon, evening and night hours. At that time, the patient no longer lived in his family home and thus his parents no longer had control over the time he was getting up and whether he ate anything in the morning. Increasing sleep problems made the patient seek medical advice once again. He was once again diagnosed with mood disorders and was given sertraline up to $100 \mathrm{mg} /$ day and then citalopram $20 \mathrm{mg}$ /day. To promote sleep, quetiapine $25 \mathrm{mg}$ /day and then perazine $25 \mathrm{mg} /$ day were recommended. Both drugs stopped to be effective in spite of increasing the dose even to $200 \mathrm{mg} /$ day in the case of quetiapine and $100 \mathrm{mg} /$ day in the case of perazine, which caused "tingling feet" when taken at this dose. The patient himself decided to start to take mel- wowej miał problemy z zasypianiem i wstawaniem rano do szkoły. Trudności te wyraźnie narosły w okresie adolescencji. Możliwość zaśnięcia pojawiała się wówczas najczęściej dopiero o godzinie 3:00 w nocy. Z tego powodu pacjent notorycznie był niewyspany, zasypiał i spóźniał się na lekcje. Przed południem był w szkole „nieprzytomny”. Dobre samopoczucie występowało dopiero wieczorem. Godziny późnowieczorne i nocne były jego ulubionym czasem nauki, ale też korzystania dla przyjemności z komputera. Problemy ze zasypianiem i niedobór snu $\mathrm{w}$ dni szkolne pacjent kompensował, długo śpiąc $\mathrm{w}$ weekendy. Czas wstawania rano w sobotę i niedzielę stopniowo się opóźniał, nawet do godzin wczesnopopołudniowych. Klasa maturalna była dla pacjenta bardzo trudnym okresem, ponieważ nauczyciele przestali tolerować jego spóźnienia i brak aktywności na lekcjach. Wówczas rozpoczął leczenie psychiatryczne. Przyjmował typowe leki nasenne (zolpidem, zopiklon), następnie również te silniej działające (nitrazepam, estazolam). Ułatwiały one zasypianie, ale nie poprawiały istotnie funkcjonowania $\mathrm{w}$ godzinach przedpołudniowych. Stopniowo ich działanie się wyczerpywało, a próby zwiększania dawek powodowały nadmierne stłumienie rano. Pojawiły się również zaburzenia nastroju, uczucie smutku, braku radości z aktywności i stałego zmęczenia. Rozpoczęto leczenie lekami przeciwdepresyjnymi z grupy inhibitorów wychwytu zwrotnego serotoniny (pacjent zgłosił, że próbowano stosować kilka leków, które źle tolerował, ostatecznie wybrano sertralinę $50 \mathrm{mg} /$ dobę) z częściową poprawą stanu psychicznego, ale nie rytmu snu. Stan pacjenta uległ istotnej poprawie po rozpoczęciu studiów. Poprawa spowodowana brakiem konieczności wstawania rano trwała kilka miesięcy, w ciągu których rytm snu dalej się opóźniał, pory snu przesunęły się na godziny między 4:00-5:00 a 13:00-14:00. Wkrótce pacjent nie był $\mathrm{w}$ stanie uczestniczyć $\mathrm{w}$ przedpołudniowych zajęciach akademickich. Nie zaliczył ćwiczeń i został zawieszony w prawach studenta. Przez cały ten okres pacjent intensywnie korzystał z komputera wieczorem i w nocy. Rano jego aktywność była bardzo niska. $\mathrm{Na}$ godziny popołudniowe, wieczorne i nocne przesunął się również jego rytm posiłków. Pacjent mieszkał już wówczas poza domem rodzinnym, co sprawiło, że rodzicie przestali mieć kontrolę nad tym, o której wstaje i czy rano cokolwiek je. Narastające problemy ze snem sprawiły, że pacjent ponownie zwrócił się po pomoc lekarską. Ponownie rozpoznano zaburzenia nastroju, stosowano sertralinę do $100 \mathrm{mg} /$ dobę, następnie citalopram $20 \mathrm{mg} /$ dobę. W celu promowania snu zalecono kwetiapinę $25 \mathrm{mg} /$ dobę, potem perazynę $25 \mathrm{mg} /$ dobę. Oba leki przestawały działać, mimo zwiększania dawki nawet do $200 \mathrm{mg} /$ dobę dla kwetiapiny i $100 \mathrm{mg} /$ dobę dla perazyny, która w tej dawce powodowała u pacjenta "mrowienie nóg". Sam pacjent rozpoczął przyjmowanie melatoniny godzinę przed snem, czyli często dopiero o 3:00-4:00 
atonin $3 \mathrm{mg} /$ day an hour before bedtime, that is often as late as 3:00 a.m. - 4:00 a.m., and then increased its dose to $5 \mathrm{mg}$ and even $10 \mathrm{mg} /$ day in order to increase the effect of the drug. The patient also observed that sitting up all night made it possible for him to fall asleep the next day around midnight and get up in the morning at 8:00 a.m. - 9:00 a.m. He used this method before important meetings in the morning in order to make his sleep rhythm return to normal. After several months of functioning in this way, the patient noticed that his sleep rhythm became flexible and started to "shift forward". This means that after a week with the period of sleep between 4:00 a.m. 5:00 a.m. and 1:00 p.m. - 2:00 p.m. typical for the patient there was a period of approximately 7 days when he slept only during the day. Then, the time of sleep returned to normal and for approximately 6-7 days the patient was able to sleep between 0:00 and 8:00 a.m. Dysregulation of sleep also led to increased demand for sleep. On the day on which the patient reported to the clinic, the patient said that he needed 13 hours of sleep. He also said that he took the following drugs: mirtazapine $30 \mathrm{mg} /$ day and lamotrigine $100 \mathrm{mg} /$ day. When asked why he took lamotrigine, he answered that his doctor said that this drug would return his unstable sleep rhythm to normal.

In the sleep disorder outpatient clinic, he was preliminary diagnosed with delayed sleep-wake phase disorder which, as a result of bad practices involving the use of the computer and electric light very late at night, sleeping off at weekends, the lack of a regular rhythm of activity and meals during the day, taking melatonin too late and taking it at too high doses, as well as finally the introduction of the periods of total sleep deprivation into the sleep rhythm, turned into a disorder with the sleep and wake rhythm longer than 24 hours.

In the course of treatment, just before the patient's sleep rhythm aligned with the hours of sleep between 0:00 and 8:00 a.m. desired by him, strict adherence to regular activity for the period of six weeks was applied, combined with taking melatonin $5 \mathrm{mg}$ /day in the evening three hours before the planned time of going to bed and avoiding light after taking it, as well as the exposure to light in the morning in the form of phototherapy on cloudy days or intensive marching outdoors on sunny days (Table 1).

As expected, the patient did not completely follow the received recommendations (Table 1). Consequently, the behavioural intervention had to be repeated several times. Due to patient's complaints about the morning dullness and confirmed length of sleep significantly exceeding typical average period of sleep for persons at the same age as that of the patient, it was decided to discontinue mirtazapine. The lamotrigine was also discontinued. These drugs were replaced by quetiapine $50 \mathrm{mg} /$ day taken an hour before going to bed. During subsequent checkups, the patient reported that his sleep rhythm got stabilised in the period between 1:00 a.m. and 9:00 a.m. w nocy, w dawce $3 \mathrm{mg} /$ dobę, którą następnie zwiększył do 5 , a nawet $10 \mathrm{mg} /$ dobę, chcąc zwiększyć efekt leku. Dodatkowo pacjent zaobserwował, że „zarwanie całej nocy" powoduje, że kolejnego dnia jest w stanie zasnąć około północy i rano wstać o 8:00-9:00. Przed ważnymi spotkaniami rano korzystał z tej metody, aby unormować rytm snu. Po kilkunastu miesiącach takiego funkcjonowania pacjent spostrzegł, że jego rytm snu stał się ruchomy, zaczął „przesuwać się do przodu”, tzn. po tygodniu $\mathrm{z}$ typową dla pacjenta porą snu od godziny 4:00-5:00 rano do 13:00-14:00 po południu następował ok. 7-dniowy okres, kiedy sen występował tylko w dzień. Następnie pory snu się normalizowały i przez ok. 6-7 dni pacjent był $\mathrm{w}$ stanie sypiać $\mathrm{w}$ porach 0:00-8:00. Rozregulowanie snu spowodowało również zwiększenie zapotrzebowania na sen. $\mathrm{W}$ dniu zgłoszenia się do ośrodka pacjent twierdził, że jego potrzeba snu wynosi 13 godzin. Zgłosił on również przyjmowanie następujących leków: mirtazapina $30 \mathrm{mg} /$ dobę oraz lamotrygina $100 \mathrm{mg} /$ dobę. Pytany o powód przyjmowania lamotryginy poinformował, że jego lekarz stwierdził, że lek ten unormuje niestabilny rytm snu.

W poradni leczenia zaburzeń snu postawiono wstępną diagnozę zaburzenia z opóźnioną fazą snu i czuwania, które w wyniku niewłaściwego postępowania - w postaci korzystania z komputera i światła elektrycznego do godzin późnonocnych, długiego odsypiania niedoboru snu w weekendy, braku regularnego rytmu aktywności i posiłków w ciągu dnia, zbyt późnego przyjmowania melatoniny oraz stosowania jej w zbyt wysokich dawkach, a także ostatecznie wprowadzenia do rytmu snu okresów całkowitej deprywacji snu - przekształciło się w zaburzenie z dłuższym niż 24-godzinny rytmem snu i czuwania.

W leczeniu tuż przed zrównaniem się rytmu snu pacjenta z pożądanymi przez niego godzinami snu 0:00-8:00 zastosowano przez 6 tygodni ścisłe przestrzeganie regularnej aktywności w połączeniu z przyjmowaniem melatoniny wieczorem w dawce $5 \mathrm{mg} /$ dobe trzy godziny przed planowanym czasem snu oraz unikaniem światła po jej przyjęciu, a także ekspozycję na światło rano w postaci fototerapii $\mathrm{w}$ dni pochmurne lub intensywnego marszu na zewnątrz w dni słoneczne (tab. 1).

Pacjent zgodnie $\mathrm{z}$ oczekiwaniami nie w pełni stosował się do otrzymanych zaleceń (tab. 1). W konsekwencji interwencja behawioralna musiała zostać powtórzona kilkakrotnie. Ze względu na skargi pacjenta na stłumienie poranne i potwierdzoną długość snu znacznie ponad typowy średni czas snu dla osób w wieku pacjenta zdecydowano o odstawieniu mirtazapiny, przerwano również leczenie lamotryginą, zastępując te leki leczeniem kwetiapiną w dawce $50 \mathrm{mg} /$ dobę, godzinę przez snem. Podczas kolejnych wizyt kontrolnych pacjent opisał, że jego rytm snu uległ stabilizacji w godzinach 1:00-9:00. Zgodnie z otrzymaną od leka- 
Table 1. Plan of behavioural treatment combined with treatment with melatonin $5 \mathrm{mg} /$ day and phototherapy 10,000 lux for 30 minutes

Tabela 1. Plan leczenia behawioralnego w połączeniu z leczeniem melatoniną 5 mg/dobę i fototerapią 10000 luksów przez 30 minut

\begin{tabular}{|c|c|c|c|c|c|c|c|c|}
\hline \multirow[b]{2}{*}{ Activity/Czynność } & \multirow{2}{*}{$\begin{array}{l}\text { Time } \\
\text { agreed with } \\
\text { the patient/ } \\
\text { Pora ustalona } \\
\text { z pacjentem }\end{array}$} & \multicolumn{7}{|c|}{ Time of activity/Pora wykonania czynności } \\
\hline & & $\begin{array}{l}\text { Thursday/ } \\
\text { Czwartek }\end{array}$ & $\begin{array}{l}\text { Friday/ } \\
\text { Piątek }\end{array}$ & $\begin{array}{l}\text { Saturday/ } \\
\text { Sobota }\end{array}$ & $\begin{array}{l}\text { Sunday/ } \\
\text { Niedziela }\end{array}$ & $\begin{array}{c}\text { Monday/ } \\
\text { Poniedziałek }\end{array}$ & $\begin{array}{l}\text { Tuesday/ } \\
\text { Wtorek }\end{array}$ & $\begin{array}{l}\text { Wednesday/ } \\
\text { Środa }\end{array}$ \\
\hline $\begin{array}{l}\text { Waking up/Alarm clock/ } \\
\text { Pobudka/budzik }\end{array}$ & 7:00 a.m. & 7:00 a.m. & 7:20 a.m. & 7:00 a.m. & 7:00 a.m. & 8:00 a.m. & 6:55 a.m. & 6:55 a.m. \\
\hline $\begin{array}{l}\text { Getting out of bed, cold } \\
\text { shower/ } \\
\text { Wstanie z łóżka, chłodny } \\
\text { prysznic }\end{array}$ & $\begin{array}{l}\text { 7:00 a.m.- } \\
\text { 7:40 a.m. }\end{array}$ & 7:43 a.m. & 8:18 a.m. & $7: 25$ a.m. & 10:10 a.m. & $8: 30$ a.m. & 6:55 a.m. & 8:05 a.m. \\
\hline $\begin{array}{l}\text { Phototherapy/March on } \\
\text { sunny days/ } \\
\text { Fototerapia/Marsz w dni } \\
\text { słoneczne }\end{array}$ & $\begin{array}{l}\text { 7:45 a.m.-- } \\
\text { 8:15 a.m. }\end{array}$ & $\begin{array}{l}\text { None/ } \\
\text { Brak }\end{array}$ & 10:50 a.m. & $7: 50$ a.m. & $\begin{array}{l}\text { None/ } \\
\text { Brak }\end{array}$ & None/Brak & 7:50 a.m. & $8: 50$ a.m. \\
\hline $\begin{array}{l}\text { Breakfast/Medicines/ } \\
\text { Śniadanie/Leki }\end{array}$ & $\begin{array}{l}\text { 8:15a.m.- } \\
\text { 8:30 a.m. }\end{array}$ & 8:20 a.m. & 9:00 a.m. & $8: 40$ a.m. & $11: 15$ a.m. & $8: 30$ a.m. & 8:30 a.m. & $8: 30$ a.m. \\
\hline $\begin{array}{l}\text { March to school/work/ } \\
\text { Marsz do szkoły/pracy }\end{array}$ & $\begin{array}{l}\text { 8:40 a.m.- } \\
\text { 9:00 a.m. }\end{array}$ & 3:00 p.m. & 10:50 a.m. & $\begin{array}{l}\text { None/ } \\
\text { Brak }\end{array}$ & $\begin{array}{l}\text { None/ } \\
\text { Brak }\end{array}$ & 10:05 a.m. & $10: 40$ a.m. & 10:00 a.m. \\
\hline $\begin{array}{l}\text { Start of work/learning/ } \\
\text { household chores on } \\
\text { holidays/ } \\
\text { Rozpoczęcie pracy/ } \\
\text { nauki/obowiqzków } \\
\text { domowych w dni wolne }\end{array}$ & $9: 00$ a.m. & 3:40 p.m. & $11: 20$ a.m. & $\begin{array}{l}\text { None/ } \\
\text { Brak }\end{array}$ & $\begin{array}{l}\text { None/ } \\
\text { Brak }\end{array}$ & 10:30 a.m. & 10:55 a.m. & 10:30 a.m. \\
\hline $\begin{array}{l}\text { Supper/End of work/ } \\
\text { Switching off the computer/ } \\
\text { Kolacja/zakończenie } \\
\text { pracy/wyłączenie } \\
\text { komputera }\end{array}$ & 7:30 p.m. & 6:00 p.m. & 7:30 p.m. & 7:00 p.m. & 8:15 p.m. & 7:45 p.m. & 7:30 p.m. & 7:30 p.m. \\
\hline $\begin{array}{l}\text { Melatonin } 5 \mathrm{mg} / \text { day/ } \\
\text { Melatonina } 5 \mathrm{mg} / \text { dobę }\end{array}$ & 8:00 p.m. & 8:00 p.m. & 8:00 p.m. & 8:00 p.m. & 8:00 p.m. & 8:00 p.m. & 8:00 p.m. & 8:00 p.m. \\
\hline $\begin{array}{l}\text { Going to bed/ } \\
\text { Położenie się do snu }\end{array}$ & 11:00 p.m. & 10:30 p.m. & 11:00 p.m. & 11:00 p.m. & 10:30 p.m. & 11:10 p.m. & 10:45 p.m. & 11:00 p.m. \\
\hline
\end{tabular}

The activity log showed that the patient followed the recommendations for setting the alarm clock in the morning and going to bed in a proper manner and those for having a breakfast in the morning and ending the activity in the evening in a satisfactory manner. The greatest difficulties experienced by the patient were those related to getting up after he heard the alarm clock sound, starting the day actively and regular phototherapy./Dziennik aktywności wykazał właściwe stosowanie się pacjenta do zaleceń w zakresie ustawiania rano budzika i kładzenia się do snu, zadowalajace w zakresie spożywania rano śniadania i kończenia wieczorem aktywności. Największe problemy pacjent miał z wstawaniem po sygnale budzika, z aktywnym rozpoczynaniem dnia oraz regularnym stosowaniem fototerapii.

In accordance with the advice received from the doctor, he also asked for help his family members. Going to work, they were to drop in at his apartment in the morning and check whether he had woken up. The patient deemed it very useful to start the day in such a way that after getting up he was doing exercises focused on the muscles of the back and abdomen and press-ups for 20-25 minutes to the rhythm of training from his mobile phone application, then was taking a cold shower and leaving his apartment as soon as possible, trying to go to his university riding a bicycle as often as possible. By doing so, he can take quetiapine only as needed, several times a week at the dose of 12.5-25 mg/day. As a result of the obtained improvement, it was also agreed with the patient that the dose of melatonin would be reduced to $1 \mathrm{mg} /$ day and discontinued after the next 8 weeks. rza radą poprosił również o pomoc członków rodziny, aby idąc do pracy, zaglądali rano do jego mieszkania i sprawdzali, czy wstał. Jako bardzo pomocne pacjent opisał rozpoczynanie dnia w taki sposób, że po wstaniu przez 20-25 minut ćwiczy mięsnie grzbietu, brzucha i pompki w rytm treningu $z$ aplikacji na jego telefon komórkowy, następnie bierze zimny prysznic, je śniadanie, wypija kawę i jak najszybciej wychodzi z domu, starając się jak najczęściej jeździć na uczelnię rowerem. Postępowanie takie sprawia, że kwetiapinę może stosować tylko doraźnie, kilka razy w tygodniu w dawce 12,5-25 mg/dobę. W wyniku uzyskanej poprawy uzgodniono również z pacjentem zmniejszenie dawki melatoniny do $1 \mathrm{mg} /$ dobę i po kolejnych 8 tygodniach jej odstawienie. 


\section{COMMENT}

A sleep rhythm delay is a typical reaction of the body to using artificial light until late in the evening or at night. The longer the activity performed using the artificial light is continued and the more the end of the exposure to light gets closer to the period of the minimum core temperature of the body, which usually occurs about three hours before the time of the end of sleep typical of a given person, the longer this delay [3]. Other factors which increase the negative effect of light on sleep is the exposure to light at a close distance, e.g. from the computer screen, and using the light with a large amount of the blue colour that most strongly inhibits the secretion of melatonin $[4,5]$. This type of light is emitted by computer screens and other electronic devices. The arousing effect of light in the evening is particularly noticeable in the case of young people. In the case of children and teenagers, if the exposure to light is combined with mental activities attracting attention, such as watching favourite programs or browsing and adding posts in social media, having difficulty sleeping becomes basically a common situation. The exposure to light from the computer screen during the last hour before going to bed increases in adolescents by 1.5 times the risk of prolongation of the period of falling asleep to more than 60 minutes and shortening of sleep by more than 2 hours [6].

The effect of light that delays the sleep rhythm is particularly detrimental in teenagers also because it overlaps with a sleep phase delay that physiologically occurs in this period of life. The recommended minimum duration of sleep for teenagers of approximately 9 hours in the majority of people of this age would preferably occur in the period between 0:00-1:00 a.m. and 9:00-10:00 a.m. The use of the computer and other electronic devices after 10:00 p.m., the associated inability to quickly fall asleep and the necessity to get up in the morning too early in relation to the physiology of the body in order to get to school result in a significant shortage of sleep in the case of teenagers. If the attempts to stabilise the sleep rhythm do not involve going to bed earlier, but sleeping off and getting up late at weekends, the sleep rhythm may get further delayed, and as a result delayed sleep-wake phase sleep disorder (DSWPD) may develop.

The diagnosis of DSWPD is valid if the following criteria are met [7]:

- there is a long delay in the time of the main period of sleep in relation to the desired or required time of going to bed and waking up; there is chronic or recurrent difficulty falling asleep or waking up at the desired or required time, with complaints on the part of the patient or guardian;

- the symptoms occur for at least 3 months;

- if patients can freely choose the time of sleep, they report the improvement of its quality and duration; the duration of sleep becomes adequate to their age despite

\section{KOMENTARZ}

Opóźnienie rytmu snu jest typową reakcją organizmu na używanie do późnych godzin wieczornych lub nocnych sztucznego światła. Jest ono tym większe, im dłużej jest kontynuowana aktywność przy tego typu świetle i im bardziej zakończenie ekspozycji na światło zbliżyło się do okresu minimum temperatury głębokiej ciała, który występuje zwykle ok. 3 godziny przed typową dla danej osoby porą zakończenia snu [3]. Inne czynniki zwiększające negatywny wpływ światła na sen to ekspozycja na światło z bliskiej odległości, np. z ekranu komputera, i korzystanie ze światła o dużej ilości barwy niebieskiej, która najsilniej hamuje wydzielanie melatoniny $[4,5]$. Taki rodzaj światła jest emitowany właśnie $\mathrm{z}$ ekranów komputerów i innych urządzeń elektronicznych. Rozbudzający efekt światła w godzinach wieczornych jest szczególnie wyraźny u młodych osób. U dzieci i nastolatków, jeśli ekspozycja na światło połączona jest z przyciągającą uwagę aktywnością umysłową, np. oglądaniem ulubionych programów lub przeglądaniem i dokonywaniem wpisów w mediach społecznościowych, wystąpienie problemów z zasypianiem staje się w zasadzie sytuacją powszechną. Ekspozycja $\mathrm{w}$ ciągu ostatniej godziny przed snem na światło z ekranu komputera zwiększa u nastolatków ponad 1,5-krotnie ryzyko wydłużenia czasu zasypiania do powyżej 60 minut i wystąpienia skrócenia snu o powyżej 2 godziny [6].

Efekt światła opóźniający rytm snu jest szczególnie niekorzystny u nastolatków również dlatego, że nakłada się na fizjologicznie występujące w tym okresie życia opóźnienie fazy snu. Zalecana minimalna długość snu dla nastolatka, wynosząca ok. 9 godzin, przez większość osób w tym wieku najchętniej realizowana byłaby w godzinach 0:00-1:00 do 9:00-10:00. Korzystanie $z$ komputera i innych urządzeń elektronicznych po godzinie 22:00, związana $\mathrm{z}$ tym niemożność szybkiego zaśnięcia, konieczność wstawania rano zbyt wcześnie $\mathrm{w}$ stosunku do fizjologii organizmu, aby dojechać do szkoły, prowadzą u nastolatków do znacznego niedoboru snu. Jeśli próby jego wyrównania nie polegają na wcześniejszym chodzeniu spać, tylko na odsypianiu i późnym wstawaniu w weekendy, rytm snu może ulec dalszemu opóźnieniu, w wyniku czego może rozwinąć się zaburzenie z opóźnioną fazą snu i czuwania (delayed sleep -wake phase sleep disorder - DSWPD).

Rozpoznanie DSWPD jest uzasadnione, jeśli spełnione są następujące kryteria [7]:

- występuje znaczne opóźnienie pory głównego okresu snu w stosunku do pożądanej lub wymaganej pory kładzenia się do snu i budzenia się, występują przewlekłe lub nawracające trudności w zasypianiu lub wybudzaniu się o pożądanej lub wymaganej godzinie objawiające się skargami pacjenta lub opiekuna,

- objawy występują przez co najmniej 3 miesiące,

- gdy pacjent ma możliwość swobodnego wyboru pory snu, relacjonuje poprawę jego jakości i czasu trwania; 
of the occurrence of the delayed phase of 24-hour sleep and wake rhythm;

- sleep diaries and, if possible, actigraphy testing, kept for at least 7 days (preferably 14 days) show a delay in the period of sleep; during actigraphy monitoring, working days (work/school) and holidays (in particular those when an alarm clock is not used) should be taken into account;

- sleep disorders cannot be better explained by other occurring sleep disorders, neurological disorders, somatic disorders or mental disorders, and the use of drugs or other psychoactive substances.

The shift of the time of sleep by more than 2 hours relative to commonly accepted hours is deemed a significant delay in falling asleep and consequently waking up [8]. DSWPD symptoms can often be seen already early in childhood, because this is a genetically conditioned disorder. Approximately $40 \%$ of patients with a delayed sleep-wake phase have similar cases in their immediate family. A relationship was found between a delayed sleep-wake phase and polymorphism of several genes whose expression regulates the biological clock. These genes include PER3 and CLOCK [9]. The typical age at which patients seek medical advice is approximately 18 years of age. At this time, the delayed sleep phase overlaps with a delay in the times of sleep physiologically occurring at this age and changes to the sleep rhythm induced by the lifestyle. The estimated incidence of DSWPD in the adolescent population is 7-16\% [10]. Therefore, it is one of the most common causes of chronic sleep disorders occurring at this age, which should be routinely taken into consideration in the differential diagnosis of "insomnia" reported by teenagers. Often, to establish the correct diagnosis, it is enough to ask one question: "What is the rhythm and quality of your sleep on holidays and days off school?" As clinical experience shows, patients with DSWPD are, however, treated for many years with the diagnosis of insomnia and do not receive proper chronobiological treatment, i.e. treatment that affects biological rhythms [8]. In consequence, patients are given hypnotic drugs which have limited efficacy in DSWPD, may lead to the development of an addiction to hypnotics, and some of them (especially benzodiazepine derivatives with long half-life) can significantly impair cognitive performance during the day.

The basic form of treatment of DSWPD is monitoring of adherence to sleep hygiene rules with an emphasis on fixed, regular times of waking up (and falling asleep) both on school days and days off school (weekends), while limiting the use of multimedia devices emitting light, at least one hour before going to bed. It is also recommended to gradually speed up the time of waking up, e.g. by 15-30 minutes a week. In addition, the synchronisation and strengthening of the sleep rhythm is achieved by recommending the application of morning phototherapy długość snu staje się odpowiednia dla jego wieku, pomimo występowania opóźnionej fazy 24-godzinnego rytmu snu i czuwania,

- dzienniki snu, a w miarę możliwości badanie aktygraficzne prowadzone przez co najmniej 7 dni (najlepiej 14 dni) wykazują opóźnienie okresu snu; podczas rejestracji aktygrafią należy uwzględnić dni robocze (praca/szkoła) i dni wolne (w szczególności dni bez stosowania budzika),

- zaburzenia snu nie mogą być lepiej wyjaśnione przez inne występujące zaburzenia snu, zaburzenia neurologiczne, somatyczne bądź psychiczne, stosowanie leków lub innych substancji psychoaktywnych.

Jako istotne opóźnienie zasypiania, a w konsekwencji także budzenia się traktowane jest przesunięcie pory snu o ponad 2 godziny w stosunku do powszechnie akceptowanych godzin [8]. Cechy DSWPD można często zaobserwować już od wieku wczesnodziecięcego, ponieważ jest to zaburzenie uwarunkowane genetycznie. Około $40 \%$ pacjentów z opóźnioną fazą snu i czuwania ma podobne przypadki w najbliższej rodzinie. Stwierdzono związek opóźnionej fazy snu i czuwania z polimorfizmem kilkunastu genów, których ekspresja reguluje zegar biologiczny. Są to m.in. geny PER3 i CLOCK [9]. Typowy wiek zgłoszenia się po pomoc lekarską to mniej więcej 18. rok życia, wówczas genetycznie uwarunkowane opóźnienie fazy snu nakłada się na opóźnienie pór snu fizjologicznie występujące w tym wieku oraz zmiany rytmu snu indukowane stylem życia. Szacowana częstość występowania DSWPD w populacji młodzieży to $7-16 \%$ [10]. Jest to zatem jedna z najczęstszych przyczyn przewlekłych zaburzeń zasypiania w tym wieku, która rutynowo powinna być brana pod uwagę w diagnostyce różnicowej zgłaszanej przez nastolatków „bezsenności”. Często w celu ustalenia właściwej diagnozy wystarczy zadanie jednego pytania: „Jak wygląda rytm snu i jego jakość w okresie wakacji oraz w dni wolne od szkoły?". Jak pokazuje doświadczenie kliniczne, pacjenci z DSWPD są jednak przez całe lata leczeni $z$ rozpoznaniem bezsenności i nie otrzymują właściwego leczenia chronobiologicznego, czyli wpływającego na rytmy biologiczne [8]. Konsekwencją tego stanu jest podawanie pacjentom leków nasennych, które mają ograniczoną skuteczność w DSWPD, mogą prowadzić do rozwoju uzależnienia od leków nasennych, a część z nich (szczególnie pochodne benzodiazepiny o długim okresie półtrwania) może istotnie pogarszać funkcjonowanie poznawcze $\mathrm{w}$ ciągu dnia.

Podstawową formą leczenia DSWPD jest przestrzeganie zasad higieny snu, ze szczególnym uwzględnieniem stałych, regularnych pór wstawania (i zasypiania) zarówno w dni szkolne, jak i wolne od zajęć szkolnych (weekendy), z jednoczesnym ograniczaniem korzystania z urządzeń multimedialnych emitujących światło na co najmniej godzinę przed położeniem się do łóżka. Zaleca się też stopniowe przyspieszanie pory budzenia, np. o 15-30 min na tydzień. Ponadto zsynchronizowanie i wzmocnienie 
(30 minutes to 2 hours depending on the intensity of the used light) and melatonin treatment [8].

For the melatonin treatment to accelerate the sleep rhythm (i.e. to shift sleep to earlier hours), melatonin is to be taken at a high enough dose (usually 3-5 mg/day), at least three hours before the planned time of going to bed, and its administration must be combined with the avoidance of exposure to light from the time it has been taken $[2,8]$. Failure to follow these rules significantly reduces the efficacy of melatonin, and if it is taken too late, e.g. after midnight and additionally at a very high dose, i.e. $5-10 \mathrm{mg} / \mathrm{day}$, it may even happen that the use of melatonin will delay the sleep rhythm as a result of sustained high serum melatonin levels in the second half of the night, after the period with the minimum core body temperature, instead of accelerating it.

The final form of DWSPD treatment is chronotherapy involving the planned shifts of the time of going to bed. On each subsequent day, the patient goes to bed three hours later, until the desired time of going to bed is achieved. However, this method of treatment involves a significant risk that it will be impossible to stop the commenced shifting of the sleep rhythm and to stabilise it at the desired time. Therefore, this type of manipulation is usually done in a hospital where the hospital staff take control over the patient's sleep rhythm and after the desired rhythm is achieved, they make all efforts to make the patient leave the bed in the morning and actively start the day (cold shower, physical activity, exposure to light, meal).

All these elements were missing in the treatment of the described patient. He failed to follow sleep hygiene rules, what exacerbated his problems. The applied treatment was not chronobiological treatment, but symptomatic treatment using drugs that promote sleep, as in insomnia. An attempt to self-medicate with melatonin was done incorrectly (the drug was taken too late). Dysregulation of the rhythm of sleep deteriorated its quality. Duration of sleep needed to get enough sleep was increased. It was necessary to sleep off longer at weekends. Eventually, the attempts to synchronise the sleep rhythm by deprivation of sleep led to a complication as DSWPD turned into non-24-hour (longer than 24-hour in the described case) sleep-wake rhythm disorder.

In non-24-hour sleep-wake rhythm disorder (N24SWD), the biological day of the patient usually is a bit longer than 24 hours (more rarely a bit shorter). Therefore, the patient falls asleep and wakes up later, which results in recurrent episodes of insomnia at night and excessive sleepiness during the day This disorder is common in the case of blind people due to the lack of synchronisation of endogenous circadian rhythm to 24 hours by the rhythm of light associated with the day and night cycle. According to various authors, N24SWD occurs in $40-70 \%$ of blind people who do not react to light $[8,11]$. In persons who rytmu snu osiąga się, zalecając stosowanie porannej fototerapii (30 minut do 2 godzin w zależności od natężenia stosowanego światła) oraz leczenia melatoniną [8].

Aby leczenie melatoniną przyśpieszało rytm snu (czyli przesuwało go na wcześniejsze godziny), musi ona być podawana w wystarczająco wysokiej dawce (najczęściej 3-5 mg/dobę) co najmniej 3 godziny przez planowaną porą snu, a jej podanie musi być połączone z unikaniem ekspozycji na światło od momentu przyjęcia $[2,8]$. Nieprzestrzeganie tych reguł znacznie obniża skuteczność leku, a jeśli jest on przyjmowany zbyt późno, np. po północy, i dodatkowo w bardzo wysokiej dawce, czyli 5-10 mg/dobę, może nawet dojść do sytuacji, że jego stosowanie zamiast przyśpieszać, będzie opóźniać rytm snu w wyniku utrzymującego się wysokiego stężenia w surowicy krwi w drugiej połowie nocy, po okresie z minimum głębokiej temperatury ciała.

Ostateczną formą leczenia DWSPD jest chronoterapia, polegająca na zaplanowanych przesunięciach pory kładzenia się do snu. Każdego kolejnego dnia pacjent udaje się do łóżka trzy godziny później, aż do osiągnięcia pożądanego czasu kładzenia się do snu. Ta metoda leczenia wiąże się jednak ze znacznym ryzykiem, że raz rozpoczętego przesuwania rytmu snu nie uda się wyhamować i ustabilizować o pożądanej porze. W związku z tym tego typu manipulacje wykonuje się zwykle w warunkach szpitalnych, gdzie personel szpitala przejmuje kontrolę nad rytmem snu pacjenta, a po osiągnięciu pożądanego rytmu dokłada szczególnych starań, aby rano pacjent opuścił łóżko i aktywnie rozpoczął dzień (zimny prysznic, aktywność fizyczna, ekspozycja na światło, posiłek).

Wszystkich tych elementów zabrakło w leczeniu opisanego pacjenta. Nie przestrzegał on zasad higieny snu, co nasiliło jego problemy. Wdrożone leczenie nie było leczeniem chronobiologicznym, tylko objawowym lekami promującymi sen, jak w bezsenności. Próba samoleczenia melatoniną była wykonana błędnie (lek był przyjmowany zbyt późno). Rozregulowanie rytmu snu pogorszyło jego jakość. Długość snu potrzebna, aby się wyspać, uległa zwiększeniu. Konieczne było coraz dłuższe odsypianie $\mathrm{w}$ weekendy. Ostatecznie próby synchronizowania rytmu snu poprzez deprywację snu doprowadziły do powikłania $\mathrm{w}$ postaci przejścia DSWPD $\mathrm{w}$ zaburzenie $\mathrm{z}$ innym (w opisywanym przypadku dłuższym) niż 24-godzinny rytmem snu i czuwania.

Zaburzenie z innym niż 24-godzinny rytmem snu i czuwania (non-24-hour sleep-wake rhythm disoder - N24SWD) polega na tym, że biologiczna doba pacjenta trwa zwykle nieco dłużej niż 24 godziny (rzadziej nieco krócej). W związku z tym pacjent coraz później zasypia i budzi się, co przejawia się nawracającymi epizodami bezsenności $\mathrm{w}$ nocy i nadmiernej senności w ciągu dnia. Zaburzenie to jest częste u osób niewidomych, ze względu na brak synchronizacji endogennego rytmu okołodobowego do 24 godzin przez rytm światła związany z następowaniem po sobie dnia i nocy. Według różnych autorów N24SWD obecne 
are not blind, this disorder occurs very rarely. In practice, in can be observed only in conditions of complete isolation from external factors, e.g. during chronobiological experiments which showed that the endogenous rhythm of man is longer than 24 hours and thus it is called the circadian rhythm [2]. Another possibility of the occurrence of N24SWD is increased severity of DWSPD and total loss by the patient of synchronisation with 24-hour rhythm that so far has only been delayed [11], for example as a consequence of incorrect chronotherapy $[12,13]$.

The treatment of sleep rhythm disorders that are so severe as N24SWD requires a very strong chronobiological intervention, several weeks of strict adherence to regular activity and the use of methods that synchronise the circadian rhythm: phototherapy (except for the blind) and treatment with melatonin taken at the right time and at a high dose, i.e. 5-10 mg/day [8].

Attention should also be paid to mood and drive disorders periodically occurring in the described patient. It is a known phenomenon in DSWPD, found, inter alia, in studies conducted in the Faculty of Psychology of the University of Warsaw [14-16]. Emotion and drive regulation disorders accompanying DSWPD are frequently diagnosed by psychiatrists to be mood disorders from the group of affective disorders. In fact, however, they are most often also the consequence of dysregulated circadian rhythm. Administration of antidepressant drugs is, however, frequently recommended, particularly those from the group of serotonin reuptake inhibitors. They reduce irritability, improve cooperation in the treatment and have a synergistic effect with melatonin therapy. Frequently occurring poor tolerance of these drugs, as in the case of the described patient, may be a problem. In such cases, administration of agomelatine, a melatonergic antidepressant, is worth considering.

Concluding:

1. In teenagers and young adults, chronic sleep disorders are frequently caused by circadian rhythm disorders, particularly by sleep and wake phase delay.

2. In such situations, hypnotics have limited efficacy. The treatment of choice is the application of chronobiological interventions.

3. However, wrong times of these interventions and patients' failure to follow the recommended times of activity may significantly increase genetically conditioned sleep phase delay and even lead to complete loss of synchronisation between the sleep-wake rhythm and daynight rhythm. jest u 40-70\% niewidomych niereagujących na światło [8, 11]. U osób widzących zaburzenie to występuje bardzo rzadko. W praktyce zaobserwować je można tylko w warunkach całkowitej izolacji od czynników zewnętrznych, np. podczas eksperymentów chronobiologicznych, które wykazały, że endogenny rytm człowieka jest dłuższy niż 24 godziny i dlatego jest nazywany rytmem okołodobowym [2]. Inną możliwością wystąpienia N24SWD jest nasilenie się ciężkości DWSPD i całkowite utracenie przez pacjenta dotychczas tylko opóźnionej synchronizacji z rytmem 24-godzinnym [11], np. jako następstwo nieprawidłowo prowadzonej chronoterapii $[12,13]$.

Leczenie tak nasilonych, jak N24SWD, zaburzeń rytmu snu wymaga bardzo silnej interwencji chronobiologicznej, kilkunastotygodniowego ścisłego przestrzegania regularnej aktywności i użycia metod synchronizujących rytm okołodobowy - fototerapii (z wyjątkiem osób niewidomych) - oraz leczenia melatoniną podawaną o właściwej porze i w wysokiej dawce, czyli 5-10 mg/dobę [8].

$\mathrm{Na}$ uwagę zasługują również okresowo występujące $\mathrm{u}$ opisywanego pacjenta zaburzenia nastroju i napędu. Jest to znane zjawisko w DSWPD, stwierdzone m.in. w badaniach wykonanych na Wydziale Psychologii Uniwersytetu Warszawskiego [14-16]. Przez lekarzy psychiatrów zaburzenia regulacji emocji i napędu towarzyszące DSWPD są często oceniane jako zaburzenia nastroju z kręgu zaburzeń afektywnych. W rzeczywistości są one jednak najczęściej również następstwem rozregulowanego rytmu okołodobowego. Podanie leków przeciwdepresyjnych często jest jednak wskazane, szczególnie tych z grupy inhibitorów wychwytu zwrotnego serotoniny, gdyż zmniejszają one drażliwość, poprawiają współpracę w leczeniu oraz mają synergistyczne działanie z terapią melatoniną. Problemem może być częsta zła tolerancja tych leków, co zaobserwowano również u opisywanego pacjenta. $\mathrm{W}$ takich przypadkach warto rozważyć podanie agomelatyny, leku przeciwdepresyjnego o działaniu melatoninergicznym.

Podsumowując:

1. U nastolatków i młodych osób dorosłych przewlekłe zaburzenia zasypiania są często powodowane zaburzeniami rytmu okołodobowego, opóźnieniem fazy snu i czuwania.

2. W takich sytuacjach leki nasenne mają ograniczoną skuteczność, a leczeniem $\mathrm{z}$ wyboru jest stosowanie interwencji chronobiologicznych.

3. Niewłaściwe pory stosowania tych interwencji oraz brak przestrzegania przez pacjentów zalecanych pór aktywności mogą się przyczyniać do znacznego nasilenia genetycznie uwarunkowanego opóźnienia fazy snu, a nawet prowadzić do całkowitej utraty synchronizacji pomiędzy rytmem snu i czuwania a rytmem dnia i nocy. 
Patient complaining of an irregular sleep rhythm - case study

Pacjent skarżący się na nieregularny rytm snu - opis przypadku

\section{Conflict of interest/Konflikt interesu}

Absent./Nie występuje.

Financial support/Finansowanie

Absent./Nie występuje.

\section{References/Piśmiennicłwo}

1. Olesen J, Gustavsson A, Svensson M, Wittchen HU, Jonsson B. The economic cost of brain disorders in Europe. Eur J Neurol 2012; 19: 155-162.

2. Wichniak A, Jankowski KS, Skalski M, et al. Standardy leczenia zaburzeń rytmu okołodobowego snu i czuwania opracowane przez Polskie Towarzystwo Badań nad Snem i Sekcję Psychiatrii Biologicznej Polskiego Towarzystwa Psychiatrycznego. Część I: Fizjologia, metody oceny i oddziaływania terapeutyczne. Psychiatr Pol 2017; 61: 1-22.

3. Lewy AJ, Lefler BJ, Emens JS, Bauer VK. The circadian basis of winter depression. Proc Natl Acad Sci U S A 2006; 103: 7414-7419.

4. Brainard GC, Hanifin JP, Greeson JM, Byrne B, Glickman G, Gerner E, et al. Action spectrum for melatonin regulation in humans: evidence for a novel circadian photoreceptor. J Neurosci 2001; 21: 6405-6412.

5. Cajochen C, Munch M, Kobialka S, Kräuchi K, Steiner R, Oelhafen P, et al. High sensitivity of human melatonin, alertness, thermoregulation, and heart rate to short wave length light. J Clin Endocrinol Metab 2005; 90: 1311-1316.

6. Hysing M, Pallesen S, Stormark KM, Jakobsen R, Lundervold AJ, Sivertsen B. Sleep and use of electronic devices in adolescence: results from a large population-based study. BMJ Open 2015; 5: e006748.

7. American Academy of Sleep Medicine. The International Classification of Sleep Disorders - Third Edition (ICSD-3). Circadian Rhythm Sleep-Wake Disorders. $3^{\text {rd }}$ ed. Westchester: American Academy of Sleep Medicine; 2014.

8. Wichniak A, Jankowski KS, Skalski M, Skwarło-Sońta K, Zawilska JB, Żarowski M, et al. Standardy leczenia zaburzeń rytmu okołodobowego snu i czuwania Polskiego Towarzystwa Badan nad Snem i Sekcji Psychiatrii Biologicznej Polskiego Towarzystwa Psychiatrycznego. Część II. Diagnoza i leczenie. Psychiatr Pol 2017 [In press].

9. von Schantz M. Phenotypic effects of genetic variability in human clock genes on circadian and sleep parameters. J Genet 2008; 87: 513-519.

10. Barion A. Circadian rhythm sleep disorders. Dis Mon 2011; 57: 423-437.

11. Uchiyama M, Lockley SW. Non-24-Hour Sleep-Wake Rhythm Disorder in Sighted and Blind Patients. Sleep Med Clin 2015; 10: 495-516.

12. Oren DA, Wehr TA. Hypernyctohemeral syndrome after chronotherapy for delayed sleep phase syndrome. N Engl J Med 1992; 327: 1762.

13. Boivin DB, Caliyurt O, James FO, Chalk C. Association between delayed sleep phase and hypernyctohemeral syndromes: a case study. Sleep 2004; 27: 417-421.

14. Stolarski M, Jankowski KS, Matthews G, Kawalerczyk J. Wise "birds" follow their clock: The role of emotional intelligence and morningness-eveningness in diurnal regulation of mood. Chronobiol Int 2016; 33: 51-63.

15. Díaz-Morales JF, Escribano C, Jankowski KS. Chronotype and time-of-day effects on mood during school day. Chronobiol Int 2015; 32: 37-42.

16. Jankowski KS, Ciarkowska W. Diurnal variation in energetic arousal, tense arousal, and hedonic tone in extreme morning and evening types. Chronobiol Int 2008; 25: 577-595. 